\title{
Environmental assessment using landscape analysis methodology: the case of the Jundiaí Mirim river basin, Southeast Brazil
}

\author{
G. A. de Medeiros ${ }^{1}$, B. V. Marques ${ }^{1}$, F. H. Fengler ${ }^{1}$, \\ F. H. Machado ${ }^{1}$, J. F. L. Moraes ${ }^{2}$, A. Peche Filho ${ }^{1,2}$, R. M. Longo ${ }^{3}$ \\ \& A. I. Ribeiro ${ }^{1}$ \\ ${ }^{1}$ Universidade Estadual Paulista, UNESP, Brazil \\ ${ }^{2}$ Instituto Agronômico, IAC, Brazil \\ ${ }^{3}$ Pontifícia Universidade Católica de Campinas, PUCCAMP, Brazil
}

\begin{abstract}
Environmental damage and impacts from anthropogenic activities has led to the need for methodological development for its evaluation to subsidize environmental and human health management models. In this context, landscape analysis is a technique that incorporates a set of methods and procedures for understanding and explaining the structure, properties, indexes and parameters influenced by the occupation and use of the land. The main goal of this research was to present an environmental assessment methodology to represent the landscape, in simplified form, in order to identify environmental damage and impacts, to establish criteria and to propose management models for the Jundiaí Mirim river basin, São Paulo state, Brazil. This approach integrates fundamental methodological procedures through compartmentation, stratification, highlighted elements, characterization and evaluation of the landscape, considering physical, biotic and anthropogenic indicators. The results show its potential for educational, research and extension proposals because of its simple and expeditious character. Therefore it was possible to obtain a landscape efficiency index, clear and objective, that promoted the understanding of the landscape. As guidelines for the river basin management we highlighted soil conservation plans, solid waste management and sanitation in urban areas, and land use planning to protect the supply reservoir of Jundiaí city.
\end{abstract}

Keywords: environmental impact, environmental management, planning. 


\section{Introduction}

The consequences of human activities on natural resources, human health, economy, political and social relations demand for methodologies that assess in an integrated way the impacts and damages of these activities.

In this context the landscape appears as an object of study and analysis, because it is a reflection of a series of anthropogenic pressures such as: housing and settlements, agricultural use; roads and other communication and transport structures, areas for recreation and habitat fragmentation (Antrop [1]). The same author highlights its holistic character, perceivable and dynamic that can subsidize management policies that prioritize the preservation and conservation of historic values, environmental, cultural and social landscape.

Such intrinsic characteristics led to the creation of the European Landscape Convention (ELC), whose scope is to promote landscape protection, its management and planning, and to organise European co-operation on landscape issues (Council of Europe [2]). One of the ELC documents was the European Treaties Series No. 176 which proposes in Chapter 2 (National measures), Article 6 (Specific measures), item B (Training and education) the training for specialists in landscape appraisal and operations; multidisciplinary training programmes for professionals and associations addressing landscape policy, protection, management and planning; in addition to school and University courses addressing issues related to protection, management and planning of the landscape (Council of Europe [2]).

Even though concrete policies actions to disclose the importance of landscape studies, one of the barriers for better dissemination of landscape analysis approach refers to the definitions and interpretations of the "landscape" concept itself, as indicated in a study performed with consultants and professionals in Sweden by Antonson and Akerskog [3].

Antrop [1] conceptually distinguishes "landscape" and "land", in which the first refers to our perceivable environment and is considered a common cultural commodity, while land refers to a certain well-bordered territory, in most cases organized and maintained by its owner. European Landscape Convention (ELC) also relates landscape to an area perceived by people, whose character is the result of the action and interaction of natural and/or human factors (Council of Europe [2]). These settings point to the importance of environmental perception which makes the public participation an important aspect considered in European legislation on issues related to landscape analysis (Antonson and Akerskog [3]).

The analysis of the landscape has been adopted by different authors for the evaluation of the of the anthropic activities impacts, as the urbanization (Frondoni et al. [4], Malcok et al. [5]), intensification of agricultural production (Malavasi et al. [6]), in the process of planning or design of new roads (Antonson and Akerskog [3]), in the evaluation of forest fragments of a river basin (Marques [7]), in its influence on ecosystem services (Hou et al. [8]), in the selection of sites for aquaculture (Falconer et al. [9]), in relation to the relief (Wieland et al. [10]) or in studies on biodiversity and environmental perception (Gyllin and Grahn [11]). 
In these studies, the methodological approaches to landscape analysis also differ, but there is a predominance of the use of geotechnologies, as geographical information system (GIS), and photographs or images (Falconer et al. [9], Malavasi et al. [6], Frondoni et al. [4], Gyllin and Grahn [11], Marques [7], Wieland et al. [10]), supplemented with field visual observations and questionnaires (Gyllin and Grahn [11], Marques [7], Malcok et al. [5]).

An approach that has been structured for the evaluation of the landscape is named IAC Methodology (IAC-Meth) in reference to the acronym of the Agronomic Institute (IAC), an institution in which researchers initially made their proposal and presented by Peche Filho et al. [12]. Subsequently, the Institute of Science and Technology of Sorocaba in partnership with IAC has been developing the verbalization, ways of analysis and graphical representation of the results, and the application for pedagogical proposals both in undergraduate education as post-graduation (Marques [7], França et al. [13], Bressane et al. [14], Ribeiro et al. [15]).

The present study aimed to present a methodological proposal for environmental quality assessment based on landscape analysis, applied to the case study of Jundiaí Mirim river basin, in Southeast Brazil.

\section{Study area}

The Jundiaí-Mirim river basin (JMRB) is located between latitudes $23^{\circ} 00$ ' and $23^{\circ} 30^{\prime}$ South and longitudes $46^{\circ} 30^{\prime}$ and $47^{\circ} 15^{\prime}$ West (Fengler et al. [16]). This basin is inserted in the Piracicaba, Capivari and Jundiaí watershed (PCJ), an important economic region (industrial and producer of sugar cane) of São Paulo state, but that faces problems of water scarcity and pollution (Medeiros et al. [17]).

JMRB area reaches 11,750 ha, of which $55 \%$ corresponds to the municipality of Jundiai, $36.6 \%$ to the municipality of Jarinu and $8.4 \%$ to the municipality of Campo Limpo Paulista, all inserted in the State of São Paulo, Southeast Brazil. These municipalities have around 505,000 inhabitants, of whom $80 \%$ live in Jundiaí city (IBGE [18]). It is occupied mostly by pastures, reforestation and allotments. However, urban sprawl in this basin has increased the pressure over the agricultural area and forest fragments (Freitas et al. [19], Fengler et al. [16]), still leading to a picture of water resources pollution (Beghelli et al. [20]). In 1960 s it was necessary to transpose the Atibaia river waters to the Jundiaí Mirim river, in order to meet the growing water demand of the Jundiaí city.

\section{Material and methods}

In the first step of the methodological proposal we searched for databases, publications, institutions and consultants who had knowledge on the local environmental reality, for a first understanding of the environmental context and the definition of the landscape analysis scope.

Based on this search it was identified that the river basin is the water producer area that supplies the Jundiaí city; that the scarcity of hydric resources in the 
region led to the water transfer from Atibaia river that complements the outflow of Jundiaí Mirim river; that there was a strong on-going urbanization in the basin and that it has placed at risk the capacity to produce water. These considerations led to the definition of a scope in which the analysis of the landscape was focused on the definition of guidelines for environmental management of the JMRB, considering its function of water producer.

On the second step we performed an exploratory visit in the study area to get impressions to direct the environmental assessments to be carried out.

After the previous recognition of the working area we defined a sampling plan, which had as objective to identify strategical sites for the performance of the environmental evaluations in the river basin. We used, at that time, resources for the characterization of the geographical space on a systemic way such as satellite images, topographical charts, maps of soil use and occupation, photographs of the site and/or other sources of information.

In the exploratory visit it was observed that the headwater regions of the river basin presented more preserved rural characteristics and forest fragments. The middle regions of the micro-basin were in a transition area between rural and urban environment, highlighting the real estate speculation. In the lowest region are located the water reservoirs that supply the city of Jundiaí; this region presented more urbanized scenarios, but it was possible to notice that the agricultural characteristics were still present.

Therefore, it was possible to establish 6 sampling points for the collection of information in the area, taking into account particularly the proximity to forest fragments and the main river of the river basin (Figure 1).

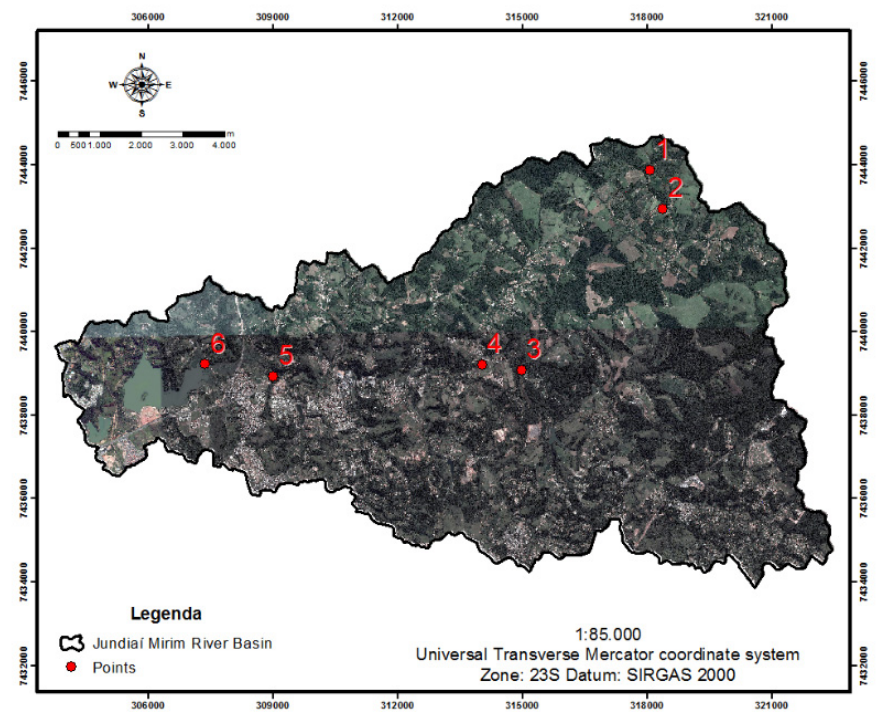

Figure 1: Roadmap to collect information in the field. 
New visits to the field occurred in September of 2014, in the points defined by the sampling plan. In each point previously selected, we made a simplified graphical representation of the landscape (Table 1), which composes IAC-Meth for landscape analysis, proposed by Peche Filho et al. [12].

Table 1: Methodology of compartmentalization and landscape stratification (Peche Filho et al. [12]).

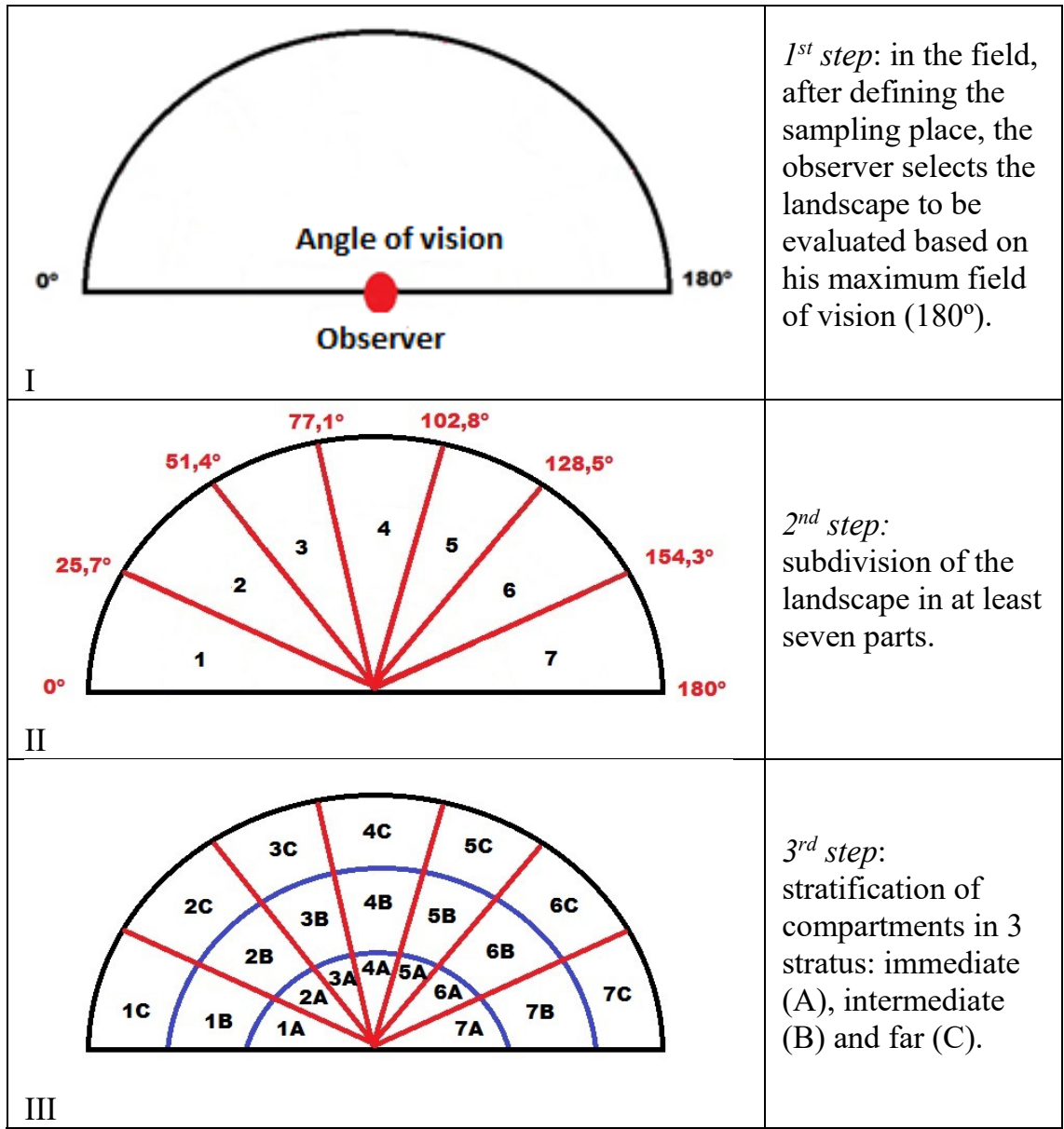

The application of IAC-Meth consisted of an analysis performed by an appraiser who positioned himself in a strategic place, where his vision ranged an angle of $180^{\circ}$ (Table $1-$ I). Later this landscape, defined by the angle of view, was segmented in seven compartments (Table $1-$ II). After that it was divided in three stratus in the horizon (immediate, intermediate and far) (Table 1 - III), making possible twenty-one units of landscape analysis for evaluation. 
The graphic representation of the landscape in compartments and stratus allowed listing at least three highlights per strata: the first one related to the physical environment, the second to the biotic environment and the third to the anthropic environment, according to the following definition (Marques [7]):

a) Physical environment: related to the dynamics between the ground, water and climate. Its interactions are essential factors to determine the environmental quality of the landscape.

b) Biotic environment: it includes all the relations and observations that involve flora and fauna, the areas of permanent preservation, legal reserve and forest fragments.

c) Anthropic environment: determined by the interaction of the human activities with the landscape, its environmental impacts, positive or negative, such as the presence of building, roads, cattle and agricultural activities, soil occupation, etc.

From these definitions (physical, biotic and anthropic environment) we extracted highlighted elements that composed the space pattern of the landscape. It must be emphasized that this analysis was based on the perception of the appraiser on the environmental impacts and damages observed, in a way to translate qualitatively what was visualized in the area in question. After the definition of the object of study (river basin) and of the highlighted elements in the landscape it was possible to initiate the stage of field evaluation.

We considered grades based on semantic differential to analyse the physical, biotic and anthropic environment varying from 1 to 5 . In this way, minimum grade 1 corresponded to the greatest perceptions of disturbance in the landscape, while the maximum grade of 5 , for perceptions of lesser disturbance and more preservation of the landscape. The processing of the grades made possible to establish an index of landscape environmental efficiency named LEI (landscape efficiency index), determined by the following equation:

$$
L E I=\frac{\sum_{i=1}^{n} x_{i}}{\sum_{i=1}^{n} y_{i}} * 100
$$

where $L E I$ corresponds to the landscape efficiency index $(\%) ; n$ the number of landscape highlighted elements analyzed for all sampling points; $x_{i}$ corresponds to the grade gotten in the evaluation process (dimensionless); $y_{i}$ corresponds to the maximum grade in the evaluation scale (dimensionless).

\section{Results and discussion}

The present study aimed to understand how the effects of water transfer and soil use and occupation affect the environmental dynamics of the river basin, emphasizing its negative environmental impacts and damages. Table 2 presents the highlighted elements used to evaluate the physical, biotic and anthropic environments for management purposes of the Jundiaí Mirim river basin. 
Table 2: Highlighted elements to evaluate the physical, biotic and anthropic environments.

\begin{tabular}{|c|c|}
\hline Highlighted elements & Description \\
\hline \multicolumn{2}{|r|}{ Physical environment } \\
\hline Erosive process & $\begin{array}{l}\text { Evidence of laminar erosion, grooves, ravines and } \\
\text { gullies. Presence of margin undermining. }\end{array}$ \\
\hline $\begin{array}{c}\text { Deposition of } \\
\text { sediments }\end{array}$ & $\begin{array}{l}\text { Accumulation of sediments transported from the highest } \\
\text { regions of the river basin. }\end{array}$ \\
\hline Surface sealing & $\begin{array}{l}\text { Reduction of infiltration by the accumulation of fine } \\
\text { ground particles on the surface. }\end{array}$ \\
\hline Risk of runoff & $\begin{array}{l}\text { Environmental vulnerability of the landscape in relation } \\
\text { to geomorphology. }\end{array}$ \\
\hline Fire risk & Fire potential of anthropic origin in forest fragments. \\
\hline \multicolumn{2}{|r|}{ Biotic environment } \\
\hline Plant diversity & $\begin{array}{l}\text { Presence of different tree species and native shrubs in } \\
\text { the landscape. }\end{array}$ \\
\hline Plant density & $\begin{array}{l}\text { Fragment tree vegetable composition, combined with } \\
\text { vegetable diversity. }\end{array}$ \\
\hline $\begin{array}{l}\text { Indications of natural } \\
\text { regeneration }\end{array}$ & Environment resilience ability. \\
\hline $\begin{array}{c}\text { Biological } \\
\text { contamination }\end{array}$ & $\begin{array}{l}\text { Presence of exotic and aggressive species such as } \\
\text { Leucaena leucocephala, Brachiaria sp., Typha } \\
\text { domingensis, Melia azedarac. }\end{array}$ \\
\hline Land cover & Ground area covered with vegetation \\
\hline Presence of fauna & Presence or evidence of insects, birds and/or mammals. \\
\hline \multicolumn{2}{|r|}{ Anthropic environment } \\
\hline Land occupation & $\begin{array}{l}\text { Regarding the human activities installed at the micro- } \\
\text { basin: agriculture, urban environment, mining, industry. }\end{array}$ \\
\hline $\begin{array}{l}\text { Potential of diffuse } \\
\text { load }\end{array}$ & $\begin{array}{l}\text { Difficult pollutant loads to be detected, factors as } \\
\text { topography and inadequate occupation are related to } \\
\text { potential diffuse load generation. }\end{array}$ \\
\hline $\begin{array}{l}\text { Soil conservation } \\
\text { practices }\end{array}$ & $\begin{array}{l}\text { Presence of soil conservation practices such as terraces, } \\
\text { no-tillage system, etc. }\end{array}$ \\
\hline Vehicle traffic & Intensity of vehicular traffic in the region. \\
\hline Condition of the roads & $\begin{array}{l}\text { Quality of the roads, presence of erosion processes and } \\
\text { generation of diffuse loads. }\end{array}$ \\
\hline Risk of accidents & $\begin{array}{l}\text { Road conditions causing risk of accidents, significant } \\
\text { impacts to the environment and human life. }\end{array}$ \\
\hline $\begin{array}{l}\text { Contamination } \\
\text { hazards }\end{array}$ & $\begin{array}{l}\text { Potential risk of environmental contamination by } \\
\text { anthropogenic activities }\end{array}$ \\
\hline Solid waste & $\begin{array}{l}\text { The presence of solid waste deposited in inappropriate } \\
\text { locations }\end{array}$ \\
\hline Border impact & $\begin{array}{l}\text { Pressure on the surroundings of forest fragments and on } \\
\text { natural environment by anthropic occupation. }\end{array}$ \\
\hline
\end{tabular}


The anthropic environment presented a bigger number of highlighted elements (Table 3), with values associated to the negative environmental conditions. Such results are explained by the non-conservationist practices of agricultural management, bad conditions of roads, amount of rubble and other types of solid waste.

Table 3: $\quad$ Results of the landscape analysis for all sites evaluated.

\begin{tabular}{|c|c|c|c|c|c|c|c|}
\hline \multirow{2}{*}{ Environment } & \multirow{2}{*}{$\begin{array}{c}\text { Landscape highlighted } \\
\text { elements }\end{array}$} & \multicolumn{6}{|c|}{ Sampling points } \\
\hline & & 1 & 2 & 3 & 4 & 5 & 6 \\
\hline \multirow{5}{*}{ Physical } & Erosive process & 1 & 1 & 3 & 2 & 2 & 3 \\
\hline & Deposition of sediments & 1 & 1 & 1 & 1 & 1 & 2 \\
\hline & Surface sealing & 1 & 2 & 1 & 2 & 1 & 3 \\
\hline & Risk of runoff & 1 & 1 & 1 & 1 & 1 & 1 \\
\hline & Fire risk & 3 & 3 & 3 & 3 & 3 & 1 \\
\hline \multirow{6}{*}{ Biotic } & Plant diversity & 4 & 4 & 2 & 2 & 3 & 3 \\
\hline & Plant density & 3 & 4 & 2 & 3 & 3 & 2 \\
\hline & $\begin{array}{l}\text { Indications of natural } \\
\text { regeneration }\end{array}$ & 3 & 2 & 2 & 1 & 3 & 1 \\
\hline & Biological contamination & 2 & 1 & 2 & 1 & 1 & 1 \\
\hline & Land cover & 3 & 3 & 1 & 2 & 2 & 3 \\
\hline & Presence of fauna & 3 & 3 & 3 & 2 & 2 & 2 \\
\hline \multirow{9}{*}{ Anthropic } & Land occupation & 1 & 2 & 1 & 1 & 1 & 2 \\
\hline & Potential of diffuse load & 1 & 1 & 1 & 1 & 1 & 1 \\
\hline & Soil conservation practices & 1 & 1 & 1 & 1 & 1 & 1 \\
\hline & Vehicle traffic & 3 & 2 & 1 & 3 & 1 & 1 \\
\hline & Condition of the roads & 1 & 1 & 2 & 2 & 1 & 3 \\
\hline & Risk of accidents & 1 & 1 & 1 & 3 & 1 & 1 \\
\hline & Contamination hazards & 1 & 1 & 1 & 1 & 1 & 1 \\
\hline & Solid waste & 2 & 3 & 1 & 1 & 1 & 2 \\
\hline & Border impact & 1 & 1 & 1 & 1 & 1 & 1 \\
\hline \multirow{4}{*}{ Results } & LEI (\%) & 37 & 38 & 31 & 34 & 31 & 35 \\
\hline & Physical LEI (\%) & 28 & 32 & 36 & 36 & 32 & 40 \\
\hline & Biotic LEI (\%) & 60 & 57 & 40 & 37 & 47 & 40 \\
\hline & Anthropic LEI (\%) & 27 & 29 & 22 & 31 & 20 & 29 \\
\hline
\end{tabular}

The landscape efficiency index varied from $31 \%$ to $38 \%$, reaching an average of $34.3 \%$ for Jundiai Mirim river basin. This range shows a critical level of environmental vulnerability according to the classification of Marques [7].

The best LEI performance was observed at the higher altitude region of the river basin (sites 1 and 2), where the rural landscape prevails.

LEI performance reduced with the increasing pressure from urban areas. The site corresponding to water transfer (point 1) had the worst grades related to physical environment, because of a large area of eucalyptus planted downhill without any conservationist soil management (Figure 2(a)). 


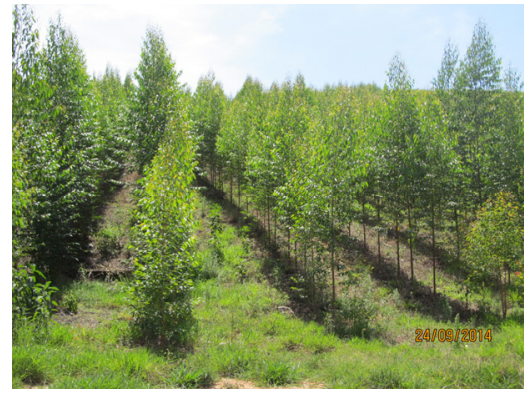

(a)

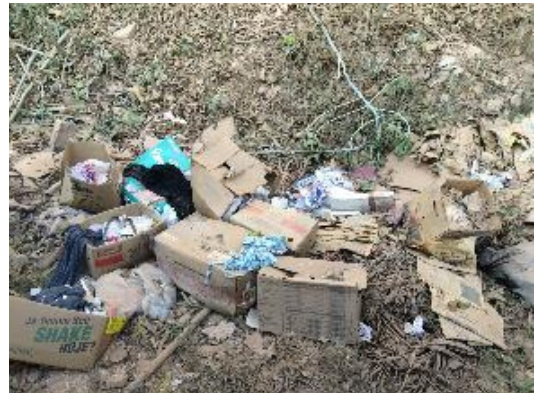

(b)

Figure 2: Landscape images from Jundiaí Mirim river basin: (a) eucalyptus planted downhill in the rural area (point 1); (b) diffuse garbage released beside the road, in the urbanized area (point 5).

On the other hand, the diversity of vegetation and the ground cover led to the biggest observed landscape efficiency $(60 \%)$, considering all the evaluated areas. This performance raised the average LEI to $37 \%$ (point 1), the second highest among the evaluated sites.

The biggest LEI was also observed in JMRB rural areas (point 2), and reached $38 \%$. However this value should still be considered as an indicator of critical vulnerability, because in this area were identified sources of contamination by improper disposal of pesticide packaging and removal of riparian vegetation.

In the biotic environment the effect of urbanization was visible in the landscape by the suppression of vegetated areas, and especially the introduction of exotic species. Considering the anthropic environment, we observed the lowest LEI in the most urbanized area (point 5), highlighting the diffuse garbage (Figure 1(b)), the poor road conditions, the risk of accidents and pollution potential by sewage release. The increase of Jundiaí Mirim river flow, due to water transfer, has caused margin undermining, especially in the most urbanized areas of the river basin. These results allowed us to propose environmental management programs for each evaluated environmental dimension (physical, biotic and anthropogenic), which are priorities for the Jundiai Mirim river basin (Table 4)

\section{Conclusions}

IAC methodology presents applicability in several situations; therefore the highlighted elements depend on the scope of landscape analysis. Field works and analyses were carried out with few resources, accessible to public managers or other social sectors, such as photographs, satellite images and secondary data. The methodological proposal pointed out the high pressure caused by the urbanization process, highlighting water transfer, waste disposal and suppression 
of riparian area, showing the need of public policies for the improvement of the environmental conditions in Jundiaí Mirim river basin.

Table 4: $\quad$ Programs for landscape management in Jundiaí Mirim river basin.

\begin{tabular}{|l|l|}
\hline Environment & \multicolumn{1}{|c|}{ Programs of environmental management } \\
\hline \multirow{4}{*}{ Physic } & Soil conservation \\
\cline { 2 - 2 } & Water quality monitoring \\
\cline { 2 - 2 } & Sanitation \\
\hline \hline \multirow{3}{*}{ Biotic } & Land reclamation \\
\cline { 2 - 2 } & Recovery of riparian area \\
\cline { 2 - 2 } & Introducing native vegetative species \\
\hline \hline \multirow{4}{*}{ Anthropic } & Urban planning \\
\cline { 2 - 2 } & Waste management \\
\cline { 2 - 2 } & Road maintenance \\
\cline { 2 - 2 } & Environmental education \\
\cline { 2 - 2 } & Protection of the reservoirs border area \\
\hline
\end{tabular}

\section{Acknowledgement}

The authors thank the Pro Reitoria de Pós Graduação, Univ. Estadual Paulista (UNESP), from São Paulo state, Brazil for the financial support.

\section{References}

[1] Antrop, A. Background concepts from integrated landscape analysis. Agriculture, Ecosystems and Environment, 77, pp. 17-28, 2000.

[2] Council of Europe. The European Landscape Convention. European TreatySeries (CETS), N. 176, 2000.

[3] Antonson, H., Akerskog, A. "This is was we did last time". Uncertainty over landscape analysis and its procurement in the Swedish road planning process. Land Use Policy, 42, pp. 48-57, 2015.

[4] Frondoni, R., Mollo, B., Capotorti, G. A landscape analysis of land cover change in the Municipality of Rome (Italy): spatio-temporal characteristics and ecological implications of land cover transitions from 1954 to 2001. Landscape and Urban Planning, 100, pp. 117-128, 2011.

[5] Malcok, E., Kilicaslan, C., Ozkan, M.B. Visual landscape analysis of urban open spaces: a case study of the coastline of Göcek settlement, Mugla, Türkiye. Indoor and Built Environment, 19, pp. 520-537, 2010.

[6] Malavasi, M., Santoro, R., Cutini, M., Acosta, A.T.R., Carranza, M.L. What has happened to coastal dunes in the last half century? A multitemporal coastal landscape analysis in Central Italy. Landscape and Urban Planning, 119, pp. 54-63, 2013. 
[7] Marques, B.V. Assessment in protective environments of Jundiaí-Mirim river basin. MSc. Thesis, Universidade Estadual Paulista, Sorocaba city, São Paulo state, Brazil, 2016 (in Portuguese).

[8] Hou, Y., Burkhard, B., Müller, F. Uncertainties in landscape analysis and ecosystem service assessment. Journal of Environmental Management, 127, pp. S117-S131, 2013.

[9] Falconer, L., Hunter, D.C., Telfer, T.C., Ross, L.G. Visual, seascape and landscape analysis to support coastal aquaculture site selection. Land Use Policy, 34, pp. 1-10, 2013.

[10] Wieland, R., Dalchow, C., Sommer, M., Kyoko, F. Multi-scale Landscape Analysis (MSLA) - a method to identify correlation of relief with ecological point data. Ecological Informatics, 6, pp. 164-169, 2011.

[11] Gyllin, M., Grahn, P. Semantic assessments of experienced biodiversity from photographs and on-site observations - a comparison. Environment and Natural Resources Research, 5(4), pp. 46-62, 2015.

[12] Peche Filho, A., Freitas, E.P., Ribeiro, A.I. et al. IAC methodology for landscape analysis. In Proc. XI Nat. Congress on Environment of Poços de Caldas. 1-9. Poços de Caldas - MG, Brazil. 2014 (in Portuguese).

[13] França, L.V.G., Bressane, A., Silva, F.N., Peche Filho, A., de Medeiros, G., Ribeiro, A.I. et al. Fuzzy Modelling applied to the Analysis of Landscape: a proposal for participatory environmental assessment. Fronteiras, 3(3), pp. 124-141, 2014 (in Portuguese).

[14] Bressane, A., Medeiros, G.A., Ribeiro, A.I., Peche Filho, A. Constructivist approach integrating teaching, research and application to reality: the case of the graduate program in Environmental Sciences of UNESP Sorocaba. Revista Brasileira de Pós Graduação, 12(27), pp. 251-276, 2015 (in Portuguese).

[15] Ribeiro, A.I., Peche Filho, A., Medeiros, G.A., Longo, R.M., Storino, M., Fengler, F.H., Keller, E.M.L., Rapp, J.Z. and Freitas, E.P. Environmental diagnosis in areas with different use and occupation using the perception of diverse biological activity. WIT Transactions on Ecology and the Environment, 162, pp. 129-136, 2012.

[16] Fengler, F.H., Moraes, J.F.L., Ribeiro, A.I., Peche Filho, A., Storino, M., de Medeiros, G. Environmental quality of forest fragments in JundiaíMirim river basin between 1972 and 2013. Revista Brasileira de Engenharia Agrícola e Ambiental, 19(4), pp. 402-408, 2015 (in Portuguese).

[17] Medeiros, G.A., Tresmondi, A.C.C.L., de Queiroz, B.P.V., Melo, C.A., Rosa, A.H., Negro, C.V., Fraceto, L.F. and Ribeiro, A.I. Evaluation of metals in water and sediments of micro-basins in the city of Americana, São Paulo state, Brazil. WIT Transactions on Ecology and the Environment, 172, pp. 201-212, 2013.

[18] IBGE - Brazilian Institute of Geography and Statistics. Estimates of the resident population in Brazil and federative units. Brasília: IBGE, 2014 (in Portuguese). 
36 Environmental Impact III

[19] Freitas, E.P., Moraes, J.F.L., Peche Filho, A., Storino, M. Environmental indicators for areas of permanent preservation. Revista Brasileira de Engenharia Agrícola e Ambiental, 17(4), pp. 443-449, 2013 (in Portuguese).

[20] Beghelli, F., Carvalho, M.E.K., Peche Filho, A., Machado, F.H. et al. Uso do índice de estado trófico e análise rápida da comunidade de macroinvertebrados como indicadores da qualidade ambiental das águas na Bacia do Rio Jundiaí-Mirim - SP - BR. Brazilian Journal of Aquatic Science and Technology, 19(1), pp. 13-22, 2015 (in Portuguese). 